ABDI: Jurnal Pengabdian dan Pemberdayaan Masyarakat ISSN: 2656-369X (Print), 2684-8570 (Online)

Volume 3 No. 2, Desember 2021

http://abdi.ppj.unp.ac.id/index.php/abdi

Email: abdi@ppi.unp.ac.id

DOI: https://doi.org/10.24036/abdi.v3i2.86

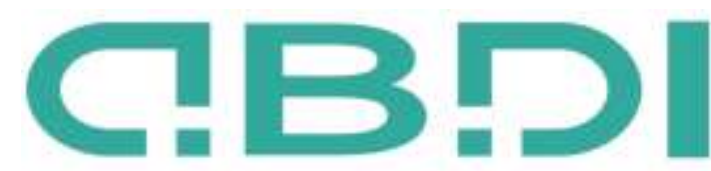

ABDE JURNAL PENGABDIAN DAN PEMBERDAYMN MUSYARAKAT

\title{
Penggunaan Alat Pengasap Ikan Berbahan bakar Biomassa pada UKM Pengasapan Ikan Lele Kota Binjai
}

\author{
Bisrul Hapis Tambunan', Janter Pangaduan Simanjuntak ${ }^{2}$, Tengku Teviana ${ }^{3}$ \\ ${ }^{1}$ Jurusan Pendidikan Teknik Mesin, Universitas Negeri Medan \\ 2 Jurusan Pendidikan Teknik Mesin, Universitas Negeri Medan \\ ${ }^{3}$ Jurusan Manajemen, Universitas Negeri Medan
}

E-mail: bisrulhapis@unimed.ac.id,janterps@gmail.com, tgtevi.unimed@gmail.com

\begin{abstract}
Abstrak
Usaha pengasapan ikan lele mitra Bapak Hatono (55 tahun) terletak di Desa Limau Sundai, Kecamatan Binjai barat, Kotamadya Binjai. Mitra memulai usaha pengasapan ikan lele sejak tahun 2014. Saat ini mitra mempekerjakan 6 orang karyawan, 1 orang sebagai mandor sekaligus bagian pengasapan, 1 orang sebagai pengemasan dan transportasi, 4 orang bagian pembelahan dan pembersihan ikan, serta mengangin-anginkan (pelembaban) setalah pengasapan ikan. Kapasitas pengolahan mitra saat ini 800-1000 kg ikan lele segar perminggu, menghasilkan $\pm 250-300 \mathrm{~kg}$ ikan lele asap per-minggu. Ikan hasil pengasapan dijual dengan harga Rp. 75.000-Rp.80.000/kg kepada pedagang, baik di daerah Kota Medan dan sekitarnya maupun ke daerah Tapanuli Utara, Tapanuli Selatan, Sibolga dan Mandailing Natal. Permasalahan utama adalah mahalnya harga kayu bakar yang dibeli dari pemasok sehingga keuntungan mitra menjadi kecil, bahkan ada kalanya ketersediaan kayu berkurang sehingga mitra harus menunda produksi sampai ada pasokan bahan bakar. Solusi utama yang diterapkan adalah merancang bangun alat pengasap ikan berbahan bakar limbah biomassa sekam padi dan serbuk kayu, dengan adanya alat ini mitra tidak kesulitan lagi dengan harga dan ketersediaan bahan bakar kayu. Alat ini juga dirancang dapat mengontrol suhu di dalam ruang pengasapan, sehingga kwalitas ikan asap dapat terjaga.

Kata kunci: Lele, Pengasapan, Pengawetan

\section{Abstract}

Partner's catfish smoking business, Mr. Hatono (55 years old) is located in Limau Sundai Village, West Binjai District, Binjai City. He started the catfish smoking business since 2014. Currently, He employs 6 employees, 1 person as the foreman as well as the fumigation department, 1 person for packaging and transportation, 4 people for clearing and cleaning fish, aerating (humidifying) after smoking. Processing capacity is currently $800-1000 \mathrm{~kg}$ of fresh catfish per week, producing $\pm 250-300 \mathrm{~kg}$ of smoked catfish per week. Smoked fish is sold for Rp. 75,000Rp.80,000 / kg to traders, both in the city of Medan and its surroundings as well as to the North Tapanuli, South Tapanuli, Sibolga and Mandailing Natal areas. The main problem is the high price of firewood purchased from suppliers so that the partners' profits are small, and sometimes there is no wood at all so the partners have to postpone production until there is a supply of fuel. The main solution to be applied is to design a fish smoker device using Biomass waste from rice husks and sawdust (biomass), with this tool Partners will have no more difficulties with the price and availability of wood fuel. This tool is also designed to control the temperature in the smoking chamber, so that the quality of the smoked fish can be maintained.
\end{abstract}

Keyword: Catfish, Fumigation, Preservation

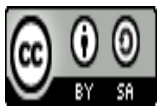

Received: 30 November $2020 \quad$ Revised: 8 Agustus $2021 \quad$ Available Online: 24 Agustus 2021 


\section{Pendahuluan}

Usaha pengasapan ikan lele milik Bapak Hatono (mitra) terletak di Desa Limau Sundai, Kecamatan Binjai barat, Kotamadya Binjai. Kecamatan Binjai Barat adalah kecamatan yang terletak di pinggiran Kota Binjai dan berbatasan dengan Kabupaten Langkat. Menurut data Badan Pusat Statistik Kota Binjai (Badan Pusat statistik kota binjai, 2018), sebagian besar Penduduk di kecamatan ini merupakan pengusaha UKM, peternak, petani dan pedagang. Dalam beberapa envent, Kecamatan Binjai Barat sering mendapat penghargaan sebagai kecamatan terbaik dalam bidang Pembinaan UKM dan pelayanan publik, baik penghargaan dari Wali Kota Binjai maupun dari Gubernur Sumatera Utara (Provsu, 2019).

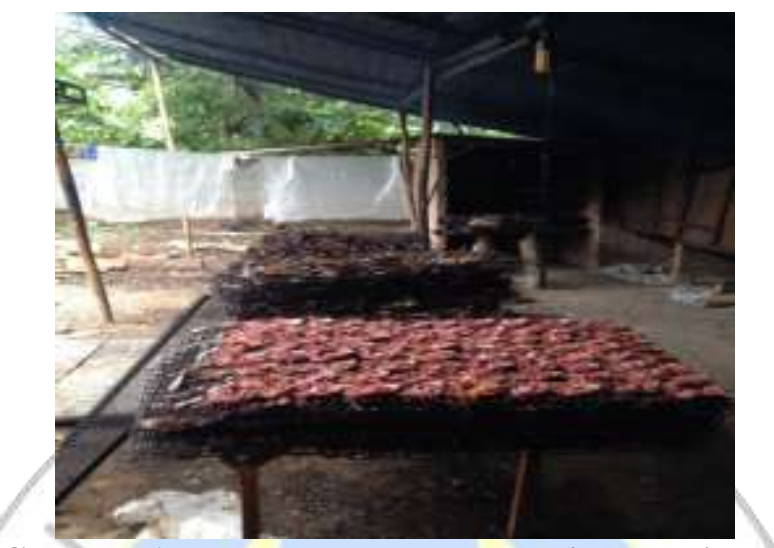

\section{Gambar 1. Ikan Lele yang sudah disusun di Rak}

Dari hasil diskusi tim pelaksana program dengan mitra didapat berbagai data dan informasi, mitra memulai usaha pengasapan ikan lele sejak tahun 2014. Awalnya mitra hanya mempekerjakan 2 orang karyawan dengan pengolahan $200 \mathrm{~kg}$ ikan lele segar/minggu yang akan mengasilkan $\pm 55 \mathrm{~kg}$ ikan lele asap. Saat ini mitra mempekerjakan 6 orang karyawan, 1 orang sebagai mandor sekaligus bagian pengasapan, 1 orang sebagai pengemasan dan transportasi, 4 orang bagian pembelahan dan pembersihan ikan, mengangin-anginkan (pelembaban) setalah pengasapan. Kapasitas pengolahan mitra saat ini 800-1000 kg ikan lele segar per-minggu, menghasilkan $\pm 250-300 \mathrm{~kg}$ ikan lele asap per-minggu. Ikan hasil pengasapan dijual dengan harga Rp. 75.000-Rp.80.000/kg kepada pedagang, baik di daerah kota medan dan sekitarnya maupun ke daerah Tapanuli Utara, Tapanuli Selatan, Sibolga dan Mandailing Natal. Ikan lele segar dibeli dari peternak dengan harga Rp. 14.000- Rp. 17.000/ kg. Mitra sudah bekerja sama dengan peternak yang bisa memasok ikan lele sesuai kebutuhan mitra.

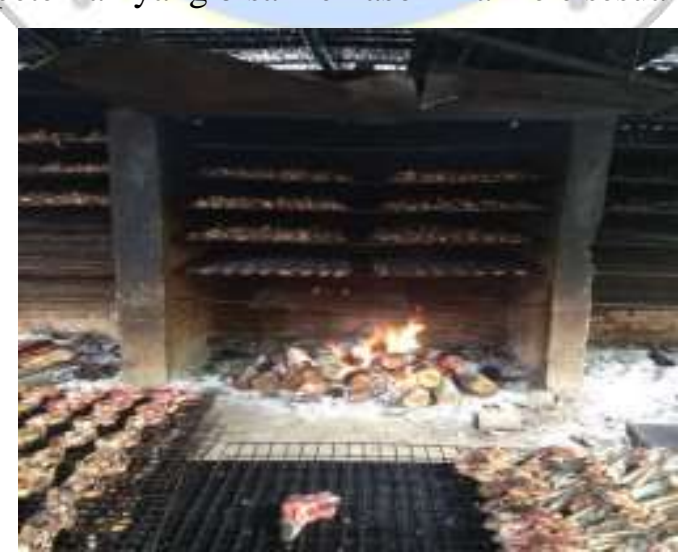

Gambar 2. Proses Pengasapan

Alat pengasapan yang digunakan mitra saat ini berupa alat pengasapan sederhana yang terbuat dari tembok semen berukuran $120 \mathrm{~cm}$ x $100 \mathrm{~cm}$ x $150 \mathrm{~cm}$. Tungku pengasapan menggunakan bahan bakar kayu dari bekas re-planting pohon karet yang dibeli dari pemasok dengan harga 1,2-1,5 juta rupiah per truck, atau sekitar 5 meter kubik. 
Besarnya biaya produksi (mahalnya harga kayu bakar), menjadi kendala tersendiri bagi mitra. Berdasarkan hasil diskusi lainnya dengan mitra, pengeluaran untuk kayu bakar membutuhkan biaya yang lebih besar dari pada biaya upah pegawai. Disisi lain, ketersediaan kayu bakar yang semakin langka menjadikan mitra sulit untuk melalukan produksi secara kontiniu. Di sisi lain menurut penelitian (Billah, 2009)(Jamilatun, Kusuma, ASS, \& Ferdiant, 2010; Saleh, Novianty, Murni, \& Nurrahma, 2017; Yudanto \& Kusumaningrum, 2009). Serbuk gergajian kayu dapat di jadikan bahan bakar karena memiliki nilai kalor yang tinggi. Disekitar lokasi mitra juga banyak terdapat kilang padi yang mengasilkan sekam sebagai limbah. Dalam beberapa penelitian menyimpulkan bahwa sekam juga layak dijadikan sebagai bahan bakar alternatif. (Puspita et al., n.d.; Syaiful, Dinata, \& Hidayattullah, 2018; Winata, 2013). Permasalahan lain yang dihadapi mitra adalah pada kemasan ikan lele asap. Kemasan yang selama ini dimiliki mitra hanya menggunakan plastik bening, sementara menurut berbagai penelitian, kemasan produk sangat perpengaruh terhadap minat konsumen membeli produk.(Darmawan, 2017; Resmi \& Wismiarsi, 2015; Susetyarsi, 2012). Oleh sebab itu, untuk menanggulangi masalah mitra diperlukan transfer IPTEKS berupa alat pengasap ikan lele tipe kabinet berbahan bakar sekam dan sebuk gergaji kayu serta membuatkan desain kemasan yang tepat.

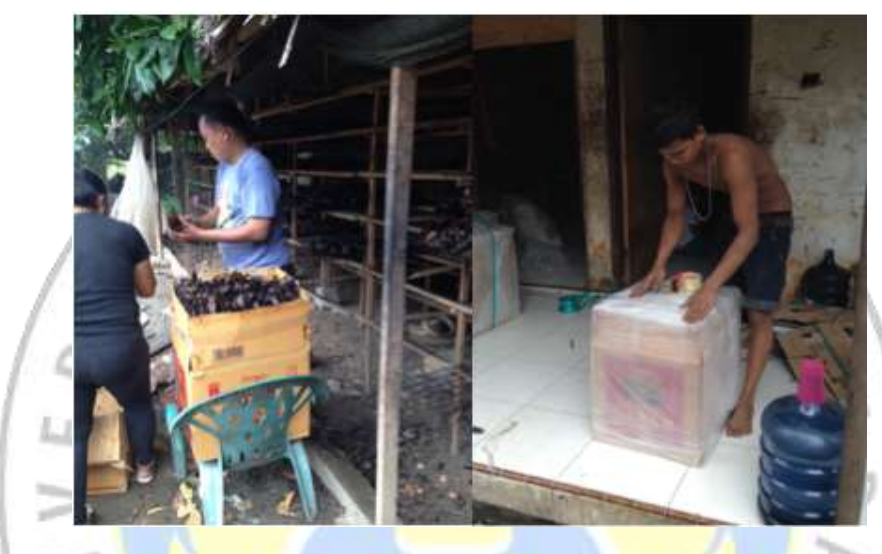

Gambar 3. Kemasan ikan lele asap

Pemilhan alat pengasap ikan lele tipe kabinet didasarkan pada banyak kajian-kajian terdahulu. Alat pengasap tipe rak dengan lama pengasapan 3 jam membutuhkan bahan bakar hanya sebanyak $60 \%$ yang menunjukkan bahwa bahan bakar dapat digunakan dalam waktu 5-6 jam, sehingga hasil produksi dapat meningkat 2 kali lipat.(Royani, Marasabessy, Santoso, \& Nurimala, 2014) Penggunaan alat pengasap lele ini memberikan efisiensi waktu pengasapan yang lebih cepat dibandingkan menggunakan proses tradisional.(Latuconsina, Rina; Pattiapon, Denny R; Nahuway, 2018) Penggunaan alat pengasapan juga menghasilkan mutu ikan yang disukai panelis.(Fansuri et al., 2011). Keuntungan lain menggunakan alat pengasap ikan lele adalah ikan matang merata, tidak tercium bau amis, warna ikan coklat muda dan bagian dalam matang, kering, bersih dan alat lebih aman serta nyaman digunakan.(Wulandari et al., 2004) Pemilihan serbuk gergaji kayu sebagai bahan bakar dikarenakan serbuk gergaji kayu menghasilkan ikan lele asap yang sangat diminati, dibandingkan dengan menggunakan tempurung kelapa. (Triwijaya K, Hariono, Djamila, \& Bakri, 2019). Berdasarkan kajiankajian di atas, tujuan dari kegitan pengabdian ini adalah untuk mendampingi mitra bidang usaha pengasapan ikan lele agar dapat menguragi biaya pembelian bahan bakar dengan menggunakan alat pengasapan ikan lele berbahan bakar biomassa dan desain kemasan yang menarik.

\section{Metode Pelaksanaan}

Metode pelaksanaan kegiatan pengabdian ini dilakukan melalui beberapa tahapan. Hal ini dikarenakan secara garis besar permasalahan yang dihadapi mitra adalah pada bidang produksi dan bidang desain kemasan. Oleh sebab itu, beberapa kegitan yang akan dilaksanakan untuk memecahkan masalah mitra. 


\subsection{Tahap Pelaksanaan Bidang Produksi}

Tahap pelaksanaan dibidang produksi dilakukan dalam beberapa tahap:

a. Berdiskusi dengan mitra tentang kebutuhan alat pengasapan lele. Proses diskusi dengan mitra menghasilkan desain alat pengasapan lele berbahan bakar biomassa dengan menggunakan rak tipe kabinet dengan bahan bakar dikedua sisisnya serta menggunakan termometer. Cerobong asap diletakkan di atas, dapat dilihat pada Gambar 4.

b. Memproduksi alat pengasapan lele sesuai dengan gambar yang telah disepakati. Proses pembuatan alat dilakukan di unit produksi Workshop Teknik Mesin Unimed. Proses pembuatan dilakukan dengan menganalisis gambar desain alat, melakukan perhitungan kebutuhan material, menentukan proses cutting plan, membuat part-part alat, melakukan assembly, melakukan uji coba, dan melakukan finishing alat.

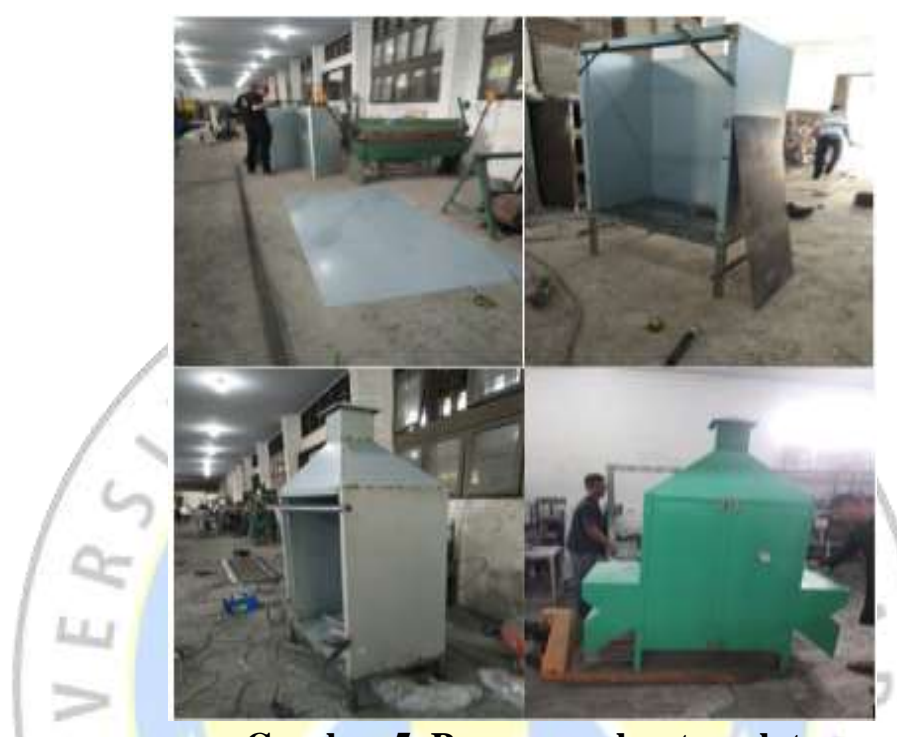

Gambar 5. Proses pembuatan alat

c. Serah-terima alat pengasapan lele didampingi tim dari LPPM. Proses serah-terima alat dilakukan dengan didampingi tim dari LPPM Unimed. Proses ini diikuti oleh seluruh anggota mitra dan anggota pengabdian di lokasi mitra.

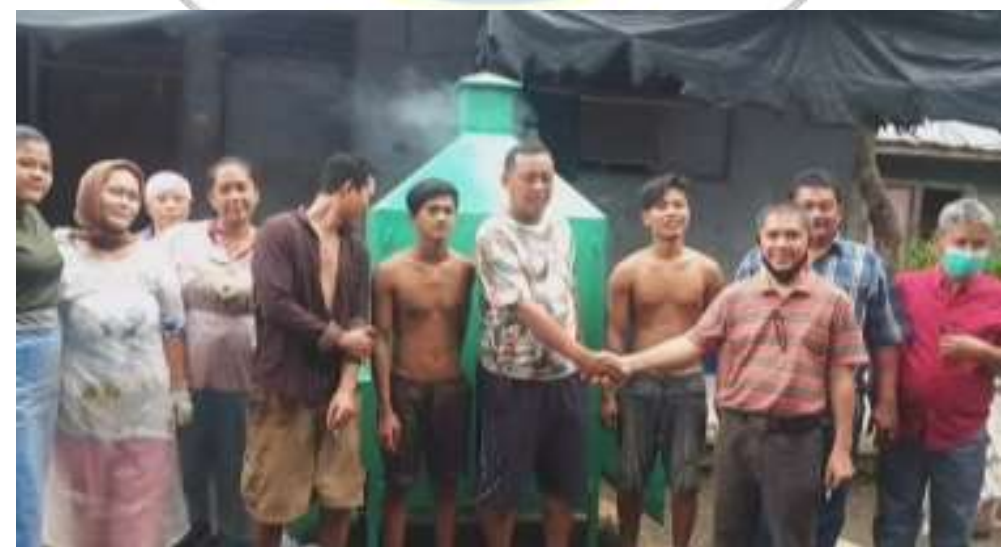

Gambar 6. Serah-terima alat pengasap lele

d. Melakukan pelatihan pengoperasian dan perawatan alat pengasapan lele. Proses pelatihan dilakukan dengan mendemonstrasikan pengoperasian alat pengasap lele dimulai dari awal hingga akhir. Pada proses ini, mitra berperan aktif untuk mencoba langsung agar memperoleh pengalaman untuk 
mendemonstrasikan alat pengasap lele. Tim pengabdian juga memberikan cara-cara perawatan mesin pada mitra.

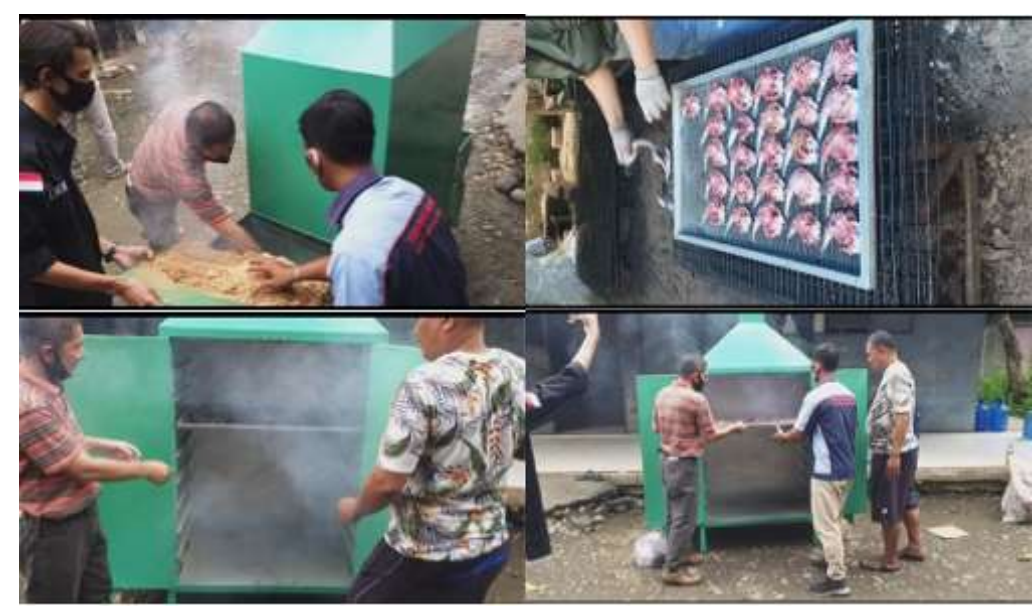

Gambar 7. Pelatihan pengoperasian alat

e. Melaksanakan pendampingan selama program berlangsung. Pendampingan dilakukan untuk memastikan semua metode solusi yang di program dilaksanakan dengan benar. Pendampingan juga untuk mengepaluasi sejauhmana kebergasilan program.

\subsection{Tahap Pelaksanaan Bidang Desain Kemasan}

a. Berdiskusi dengan mitra tentang desain kemasan lele asap. Diskusi yang telah dilakukan menghasilkan konsep desain kemasan yang telah disepakati. Desain kemasan memuat gambar Ikan asap sebagai ciri dari Mitra serta beberapa informasi tentang bisnis mitra.

b. Mendesain kemasan sesuai kebutuhan mitra

c. Memberikan desain kemasan kepada mitra.

\section{Hasil Dan Pembahasan}

\subsection{Hasil}

Kegiatan pengabidian Penggunaan Alat Pengasap Ikan Berbahan bakar Sekam dan Sebuk Kayu Pada UKM Pengasapan Ikan Lele Di Kecamatan Binjai Barat Kota Binjai telah dilaksanakan dalam beberapa tahapan pada bidang produksi dan bidang desain kemasan. Produk yang dihasilkan dari program ini adalah Alat Pengasap ikan berbahan bakar biomassa dan kemasan berlogo.
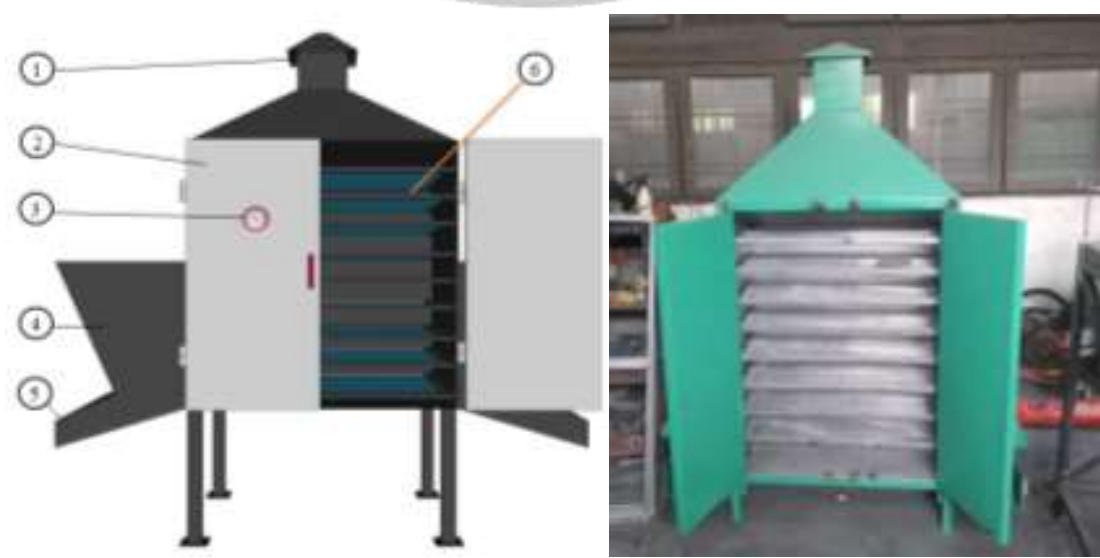

Gambar 8. Gambar desain alat pengasap ikan 
Bisrul Hapis Tambunan, Janter Pangaduan Simanjuntak, Tengku Teviana Penggunaan Alat Pengasap Ikan Berbahan bakar Biomassa pada UKM Pengasapan Ikan Lele Kota Binjai

Tabel 1. Keterangan gambar alat pengasap ikan

\begin{tabular}{cll}
\hline No & Nama Bagian & \multicolumn{1}{c}{ Fungsi } \\
\hline 1 & Cerobong asap & Saluran keluar asap dari ruang pengasapan \\
\hline 2 & Pintu ruang pengasapan & $\begin{array}{l}\text { Menutup dan membuka ruang pengasapan pada saat } \\
\text { memasukkan dan mengeluarkan ikan }\end{array}$ \\
\hline 3 & Termometer & Membaca suhu di dalam ruang pengasapan \\
\hline 4 & Hoper Biomassa & $\begin{array}{l}\text { Tempat penampungan bahan bakar biomassa sekam padi } \\
\text { dan serbuk kayu }\end{array}$ \\
\hline 5 & Saluran udara pembakaran & Saluran masuknya udara untuk pembakaran biomassa \\
\hline 6 & Rak Ikan & $\begin{array}{l}\text { Tempat meletakkan ikan yang akan di asapi dalam ruang } \\
\text { pengasapan }\end{array}$ \\
\hline
\end{tabular}

Hasil desain kemasan yang telah dibuat dapat dilihat pada Gambar 9 di bawah. Hasil desain tersebut disesuaikan dengan kesepakatan dengan Mitra.

\subsection{Pembahasan}

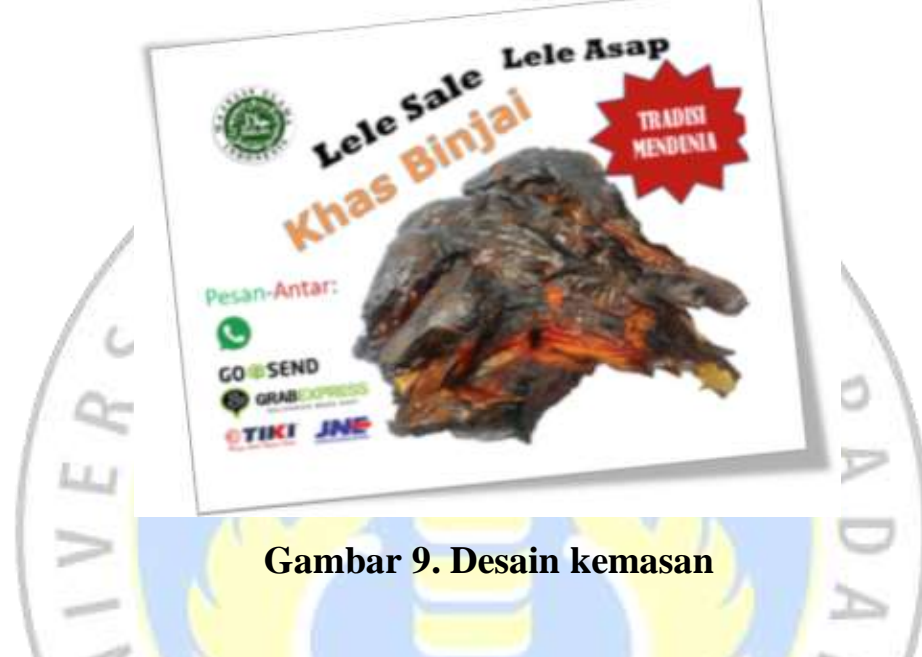

Proses pelaksanaan pengabdian Penggunaan Alat Pengasap Ikan Berbahan bakar Sekam dan Sebuk Kayu Pada UKM Pengasapan Ikan Lele Di Kecamatan Binjai Barat Kota Binjai dapat dilaksanakan secara baik tanpa ada kendala. Alat yang dibuat dapat bekerja dengan baik sesuai yang diharapkan mitra. Alat pengasap yang diberikan memberikan keuntungan efisiensi bahan bakar yang sangat signifikan sehingga dapat menekan biaya pembelian bahan bakar. Disisi lain, mitra dapat dengan mudah mengoperasikan alat pengasapan lele tersebut. Namun, keterbatasan dari alat tersebut adalah pada proses awal untuk mendapatkan temperatur yang dibutuhkan memerlukan waktu yang relatif lebih lama dibandingkan dengan proses konvensional. Akan tetapi keterbatasan ini tidak menjadi hambatan yang signifikan. Pada desain kemasan, mitra dapat menggunakan hasil desain yang telah diberikan oleh tim pengabdi dimana mitra dapat menyebarluaskan brand yang telah disepakati. Sehingga usaha mitra dapat diketahui oleh pangsa pasar.

Secara umum, hasil pengabdian ini memberikan efek yang besar terhadap hasil produksi dan pemasaran yang dilakukan oleh mitra. Pemangkasan biaya produksi dan kemasan yang lebih layak menjadi faktor utama. Bahkan, mitra yakin jika kedepannya usaha mereka dapat berkembang lebih efektif dan efisien.

\section{Kesimpulan}

Alat pengasapan lele dengan bahan bakar sekam dan serbuk gergaji kayu telah dibuat sesuai dengan kebutuhan mitra. Hasil uji efektivitas alat berjalan dengan baik sesuai yang diharapkan mitra. Sehingga, alat tersebut telah menjawab permasalah yang dihadapi mitra yakni tingginya biaya pembelian kayu bakar. Hal lainnya adalah desain kemasan yang selama ini belum dimiliki mitra telah 
Bisrul Hapis Tambunan, Janter Pangaduan Simanjuntak, Tengku Teviana Penggunaan Alat Pengasap Ikan Berbahan bakar Biomassa pada UKM Pengasapan Ikan Lele Kota Binjai

dibuat dengan hasil yang sesuai dengan kebutuhan mitra. Melalui kegitan pengabdian Penggunaan Alat Pengasap Ikan Berbahan bakar Sekam dan Sebuk Kayu Pada UKM Pengasapan Ikan Lele Di Kecamatan Binjai Barat Kota Binjai, mitra merasa terbantu dalam upaya meningkatkan produktivitas dan pemasaran usaha pengasapan ikan lele. Kedepan Tim pelaksana mrencanakan melakukan pelatihan dan pendampingan cara pemasaranan online, diharapkan dengan pemasaran online dapat menambah omset mitra.

\section{Daftar Pustaka}

Badan Pusat statistik kota binjai. (2018). Kecamatan Binjai Barat Dalam Angka (Badan Pusat statistik kota binjai, ed.). Binjai: BPS Kota Binjai.

Billah, M. (2009). Bahan Bakar Alternatif Padat (BBAP) Serbuk Gergaji Kayu. Jakarta: UPN Pres.

Darmawan, D. (2017). Pengaruh Kemasan dan Harga Terhadap Keputusan Pembelian Produk Sayuran Hidroponik. Agrimas, 1(1), 1-10

Fansuri, A., Departemen, S., Dan, I., Kelautan, T., Perikanan, F., \& Kelautan, D. I. (2011). Rancang Bangun Alat Pengasapan Dingin Berbasis Mikrokontroler. Institut Pertanian Bogor.

Jamilatun, S., Kusuma, D., ASS, S., \& Ferdiant, F. (2010). Pembuatan Biocoal Sebagai Bahan Bakar Alternatif dari Batubara dengan Campuran Arang Serbuk Gergaji Kayu Jati, Glugu dan Sekam Padi. UPN Veteran Yogyakarta.

Latuconsina, Rina; Pattiapon, Denny R; Nahuway, S. (2018). Alat Pengasapan Ikan Otomatis. Seminar Nasional Teknik Elektro, 178-180. Malang.

Provsu, B. H. (2019). Gubernur Edy Menganugerahi Binjai Barat Sebagai Kecamatan Terbaik Kategori Kota. https://diskominfo.sumutprov.go.id/artikel-1123--gubernur-edy-menganugerahi-binjaibarat-sebagai-kecamatan-terbaik-kategori-kota.html

Puspita, R. D., Desna, D., Husin, A. D., Irzaman, I., Darmasetiawan, H., \& Siswadi, S. (2010). Tungku Sekam Sebagai Bahan Bakar Alternatif Pada Sterilasasi Media Jamur Tiram. Berkala Fisika, 13(2), 45-48.

Resmi, N., \& Wismiarsi, T. (2015). Pengaruh kemasan dan harga pada keputusan pembelian minuman isotonik. Jurnal Manajemen dan Bisnis Sriwijaya, 13(1), 1-20.

Royani, D. S., Marasabessy, I., Santoso, J., \& Nurimala, M. (2014). Rekayasa Alat Pengasapan Ikan Tipe Kabinet (Model Oven). Jurnal Aplikasi Teknologi Pangan, 4(2), 74-78.

Saleh, A., Novianty, I., Murni, S., \& Nurrahma, A. (2017). Analisis kualitas briket serbuk gergaji kayu dengan penambahan tempurung kelapa sebagai bahan bakar alternatif. Al-Kimia, 5(1), 21-30.

Susetyarsi, T. (2012). Kemasan produk ditinjau dari bahan kemasan, bentuk kemasan dan pelabelan pada kemasan pengaruhnya terhadap keputusan pembelian pada produk minuman mizone di kota semarang. Jurnal STIE Semarang (Edisi Elektronik), 4(3), 1-28.

Syaiful, F. L., Dinata, U. G. S., \& Hidayattullah, Y. (2018). Pemberdayaan masyarakat melalui pemanfaatan limbah sekam padi sebagai bahan bakar kompor sekam yang ramah lingkungan di Kinali, Pasaman Barat. Buletin Ilmiah Nagari Membangun, 1(3), 62-69.

Triwijaya K, W., Hariono, B., Djamila, S., \& Bakri, A. (2019). Pengaruh Konsentrasi Asap Cair Dari Serbuk Gergaji Kayu Dan Tempurung Kelapa Terhadap Kualitas Ikan Lele Asap. Jurnal Ilmiah Inovasi, 13(3), 217-226. https://doi.org/10.25047/jii.v13i3.29

Winata, A. (2013). Karakteristik Biopelet dari Campuran Serbuk Kayu Sengon dengan Arang Sekam Padi sebagai Bahan Bakar Alternatif Terbarukan. Institut Pertanian Bogor.

Wulandari, K., Siswiyanti, S., Ubaidilah, J, Widodo, D. (2004). Pengembangan alat pengasap ikan. 165-172. Prosiding Seminar Nasional Teknoin.

Yudanto, A., \& Kusumaningrum, K. (2009). Pembuatan Briket Bioarang dari arang serbuk gergaji kayu jati. Universitas Diponegoro. 